\title{
Õppekava ja õpetaja ajas ja ruumis
}

\author{
Rain Mikser ${ }^{\mathrm{a}}$ \\ ${ }^{a}$ Tallinna Ülikooli haridusteaduste instituut
}

\begin{abstract}
McCulloch, G., Goodson, I. \& Gonzàlez-Delgado, M. (Eds.), Transnational Perspectives on Curriculum History. Oxon: Routledge, Taylor \& Francis Ltd.
\end{abstract}

Raamat „Transnational Perspectives on Curriculum History“ ilmus kirjastuse Routledge sarjas „Routledge Research in International and Comparative Education" tänavu aasta algul. Nagu toimetajad saatesõnas märgivad, ühendab väljaande ühtteistkümmet peatükki õppekavateemade ajalooline, ühiskondlik ja poliitiline käsitlus. Vaatluse all on eelkõige külma sõja ajajärgu ning sellele järgnevate õppekavamuutuste ühis- ja erijooned maailma eri paigus pea kõigis maailmajagudes.

Sissejuhatuses tutvustavad toimetajad raamatu ülesehitust ja annavad lühiülevaate õppekavaajaloo kui uurimisvaldkonna, samuti õppekavapoliitika arengust. Kuni 20. sajandi keskpaigani juhtis õppekavade arendamist eelkõige rahvusriigi idee. Sajandi teisel poolel tugevnenud üleilmastumine tähendas üha enamat sõltuvust rahvusvahelistest suundumustest - külma sõja oludes suuresti konkurentsist toonaste ida- ja läänebloki riikide vahel. Toimetajate sõnul väljendab ka sõna „transnatsionaalne” raamatu pealkirjas külma sõja aegset suundumust, mil ida- ja läänebloki maade õppekavapoliitikasse ja -sõnavarasse lisandus üha enam ühisjooni, näiteks tehnoloogiaalase mõistestiku leviku tõttu. Siiski ei ole see põhjustanud kohaliku tasandi rolli kadumist õppekava loomisel ja rakendamisel. Üks toimetajatest Ivor Goodson oli esimesi, kes hakkas 1970. aastatel inglise keeleruumis uurima, kuidas mõjutavad õppekava kujunemist varjatud poliitilised huvid, mõnikord ka avalikud võitlused eri tasandite ja huvirühmade vahel. Mõistagi on üks huvirühm õpetajad. Üleilmsete ja rahvuslike hariduseesmärkide saavutamine sõltub endiselt eelkõige õpetajast, kes õppekava koolis ja klassis rakendab. Nii võib rahvusvaheliselt heakskiidetud õppekavaalgatus sõltuvalt kohalikest teostajatest ja nende hoiakutest tegelikkuses oluliselt lahkneda algatajate kavatsustest. Selle nähtuse kirjeldamiseks kasutab Goodson refraktsiooni ehk murdumise või murrangu mõistet (vt ka Maarja Tinni artiklit käesolevas numbris). 
„Transnatsionaalsus“ avaldub raamatus mitmel viisil. Muidugi on läbiv teema üleilmse, rahvusliku ja kohaliku tasandi suhe ja vastasmõju. Selle suhte parem tundmine aitab mõista ja prognoosida õppekavamuutuste tegelikku mõju, samuti kriitilisemalt suhtuda levinud ettekujutustesse ja üldistustesse. Peatükis „Local versus national history of education“ pakuvad Johan Prytz ja Johanna Ringarp Rootsi näitel kriitilise käsituse, kuidas rahvusvaheliste ühenduste ülevaated ja võrdlusuuringud riikide vahel juhivad teadvustamatult tähelepanu kõrvale riigisisestelt erinevustelt ning tekitavad kallutatud narratiivi riigi haridusest, mille võtavad alateadlikult omaks nii välis- kui ka omamaised oppurid, praktikud ja uurijad.

Transnatsionaalsus õppekavaajaloos seostub ka rahvusliku, rassilise ja poliitilise rõhumisega ning sellest vabanemisega eri maades alates 20. sajandi keskpaigast. Neis maades tuli õppekavaloomes ja kogu hariduses korvata rõhumisest ja ebavõrdsusest tingitud puudujägid ja kallutatus, mis sundis jälgima rahvusvahelist arengut ning sellega teatud viisil suhestuma. Seda vaadet esindab Eesti-aineline peatükk „Narratives of Education and curriculum transition in the former socialist European countries: The example of Estonia" (autorid Rain Mikser ja Ivor Goodson). Tuginedes rikkalikule kirjandusele ja kogenud eesti õpetajate eluloointervjuudele, käsitlevad autorid kriitiliselt taasiseseisvumise järel levinud arusaama, nagu olnuks nõukogude ajal töötanud õpetajate loovus, algatus- ja kriitikavõime Eestis ja teistes endise idabloki maades olude tõttu tervikuna puudulik. Autorite hinnangul tingisid just nimelt toonased olud õpetajate suure tundlikkuse ja vastupanuvõime välise surve suhtes.

Rassilise, rahvusliku või poliitilise rõhumise teemast on ajendatud ka USA mustanahaliste õppekavaajalugu käsitlev „African American Curriculum History: New possibilities and directions“ (Lagarrett J. King, Alana D. Murray ja Christine Voyshner) ning ajalooline sissevaade Lõuna-Aafrika õpetajakoolituse õppekavadesse „Transnational colonial entanglements: South African teacher education college curricula“ (Linda Chisholm). Huvitava näite rahvusvaheliste ühenduste mõjust isevalitsusliku ühiskonna õppekavakorraldusele pakuvad Mariano González Delgado ja Tamar Groves, käsitledes UNESCO ja OECD vahendustegevust haridusalase telemeedia arendamiseks diktaator Francisco Franco võimu aegses Hispaanias (1936-1975).

Ajalookäsituse osas iseloomustab raamatut eri ajajärkude põimumine tänapäeva temaatikaga. Külma sõja aegne, mõnel juhul ka juba 20. sajandi alguse haridustegelikkus ja -eesmärgid on loomulik ja elav alus praeguse olukorra analüüsile.

Vähemalt kahel põhjusel väärib tähelepanu Ivor Goodsoni avapeatükk „From mystification to markets“. Esiteks põhjendab see ajalooliste uuringute vajadust õppekavade valdkonnas ning teiseks selgitab see õpetaja rolli tähtsust 
õppekava arendamisel ja rakendamisel. Sõltuvalt täpsemast määratlusest võib õppekavaajaloo kui uurimisvaldkonna alguseks lugeda 20. sajandi algust või varasematki aega. Kuni 1960. aastateni oli õppekava arendamine ja rakendamine suuresti müstifitseeritud, õppekava ja sellega seotud muutusi võeti suhteliselt enesestmõistetavana. Õppekavaajalugu piirdus enamasti varasemate õppekavade puuduste ning soovitavate muutuste kirjeldamisega, süüvimata kuigivõrd varasemate õppekavade tekke ja arengu asjaoludesse. Tagantjärele ei ole üllatav, et nii ei suudetud selgitada, miks reformidega soovitud sisulised õppekavamuutused jäid teostumata või olid parimal juhul üksnes lühiajalised. Goodson rõhutab, et õppekava tegeliku arengu mõistmiseks tuleb lisaks hetkeolukorra kriitikale ja soovitavate muutuste kirjeldamisele uurida olusid ja püüdlusi, mis juhtisid varasemate õppekavade teket ja arengut. Eriti tuleb seejuures märgata avalikke ja varjatud seaduspärasusi ning järjepidevusi.

Alates 1960. aastatest teadvustati järk-järgult, et õppekavad ning nende tavapärased koostisosad - õppeained - ei ole tegelikkuse erapooletu peegeldus, vaid need on inimeste ja inimrühmade loodud avalike ja varjatud püüdluste ning olelusvõitluse tulemusena. ${ }^{1}$ Teadvustati ka õpetaja autonoomia kahetist suhet õppekava arendamise ja rakendamisega. Ühelt poolt levisid teooriad (Goodson tõstab esile interaktsionismi), mis rõhutasid õpetaja autonoomiat, vahetu klassikontakti ja õpetaja isiklikku rolli õppimises. Teisalt tunnistati, et ka õpetaja on õppekavale tunnusliku olelusvõitluse osa: püüeldes autonoomia poole, on ta samas professionaalina oma kogukonna - aineühenduse - liige. Teda seob ametikaaslastega sarnane roll, ettevalmistus, kvaliteedinõuded ja identiteet. Säilitamaks avalikku tunnustust professionaalina, sealhulgas teiste ainete õpetajate silmis, peab ta osa autonoomiast paratamatult loovutama professionaalsele kogukonnale, kuhu ta kuulub.

Ehkki uusliberalismist hariduses on viimasel ajal Eestiski kirjutatud, väärib mainimist Goodsoni tõdemus, et just uusliberaalsed reformid õppekavapoliitikas alates 1980. aastatest tõid kaasa uuringute enneolematu tähelepanu õpetaja kui reformide peamise elluviija elule ja tööle. Juba kümnend või paar varem alanud huvi õppekavaloome varjatud seaduspärasuste vastu sai seega uue tõuke: õpetajate elulood ja nende töökogemuse uurimine sai nii metodoloogiliselt kui ka sisuliselt olulise koha senises valdavalt dokumendianalüüsil põhinevas õppekavaajaloo uuringus.

Üksikasjalikumatest õppekavaajaloo uurimustest sisaldub raamatus veel „Physics for the enquiring mind“ (Gary McCulloch), mis käsitleb füüsika õppekava projekti arendamist Suurbritannias 1960. aastatel. Nimetatud projekti

Nii Eestis kui mujal võib selle näiteks pidada väitlusi õppeainete mahtude üle mistahes haridusastmes (RM). 
peetakse esimeseks varaseks algatuseks kehtestada Suurbritannias riiklik õppekava. Veel käsitletakse Jaapani ja Suurbritannia óppekavaalaste kontaktide ajalugu (Mari Hiraoka), õppekavaajalooalaseid uuringuid Hiinas ja Taiwanis (Caixia Peng), stenograafiaõpingute kui haridusliku uuenduse ajalugu Brasiilias ja Prantsusmaal (Diana Gonçalves Vidal) ning riikliku õppekavapoliitika kajastusi ja tõlgendusi Portugali õpetajate elulugudes (Elsa Estrela). 